\title{
ANALISIS PENGELOLAAN ALAT DAN BAHAN PRAKTIKUM PADA LABORATORIUM KIMIA DI SMA NEGERI 1 TAMPAKSIRING
}

\author{
Dewa Ayu Kadek Dian Shintya Dewi, Dewa Ketut Sastrawidana, Ni Made Wiratini \\ Universitas Pendidikan Ganesha, Singaraja, Indonesia \\ e-mail: dianshintyadewi@gmail.com, ketut.sastrawidana@undiksha.ac.id,
}

\begin{abstract}
Abstrak
Penelitian ini bertujuan untuk mendeskripsikan dan menjelaskan (1) pengelolaan alat dan bahan praktikum di SMA Negeri 1 Tampaksiring dilihat dari aspek perencaaan, pengadaan, penggunaan, pemeliharaan, inventarisasi, serta pemusnahan alat dan bahan yang rusak, dan (2) hambatan-hambatan yang dialami dalam mengelola alat dan bahan praktikum. Penelitian ini merupakan penelitian kualitatif dengan pendekatan fenomenologi. Data penelitian dikumpulkan melalui observasi, wawancara, dan dokumentasi. Hasil penelitian menunjukkan bahwa (1) pengelolaan alat dan bahan praktikum pada laboratorium kimia belum dilaksanakan dengan optimal, khususnya pada aspek pengadaan, penggunaan, pemeliharaan, inventarisasi, dan pemusnahan, (2) terdapat beberapa hambatan dalam mengelola alat dan bahan praktikum, yaitu a) pada proses pengadaan yaitu keterbatasan dana, b) pada penggunaan yaitu kondisi laboratorium yang digunakan sebagai ruangan kelas, kurangnya waktu, dan keterbatasan alat dan bahan praktikum, c) pada proses pemeliharaan dan inventarisasi yaitu waktu dan tenaga ahli, serta d) pada proses pemusnahan yaitu sulitnya mencari tempat untuk lubang pembuangan dan pemahaman guru yang kurang.
\end{abstract}

Kata kunci: alat dan bahan praktikum, laboratorium kimia, pengelolaan.

\begin{abstract}
This research aimed to describe and explain (1) the management of practicum equipment and materials at SMA Negeri 1 Tampaksiring viewed from the aspects of planning, procuring, utilizing, maintaining, inventoring, and disposing of the broken practicum equipment and materials, and (2) the obstacles in managing practicum equipment and materials. This research was a qualitative research with a phenomenologyy approach. The research data was collected through observation, interviews, and documentation. The results of this research show that (1) the management of practicum equipment and materials has not been implemented optimally, especially in the aspects of procuring, utilizing, maintaining, inventoring, and disposing, (2) there are several obstacles in managing practicum equipment and materials, were a) in procuring prosses is funding, b) in utilizing prosses are laboratory conditions which is used as classroom, lack of time, and the limited practicum equipment and materials, c) in maintaining and inventoring prosses are lack of time and expertise, and d) in disposing prosses are the difficulty of finding a place for drainage holes and lack of understanding of teacher.
\end{abstract}

Keywords: practicum equipment and materials, chemistry laboratory, management 


\section{PENDAHULUAN}

Pada hakikatnya ilmu kimia memiliki dua dimensi, yaitu kimia sebagai produk dan kimia sebagai proses (Depdiknas, 2003). Kimia sebagai produk berkaitan dengan pengetahuan kimia yang berupa fakta, konsep, prinsip, hukum dan teori, sedangkan kimia sebagai proses berkaitan dengan kerja ilmiah di laboratorium (BSNP, 2006). Melalui kegiatan praktikum di laboratorium siswa akan lebih termotivasi dalam belajar dikarenakan oleh terlibatnya seluruh indra dalam pengamatan dan percobaan yang dilakukan ketika praktikum berlangsung. Dengan adanya motivasi yang tinggi, siswa akan bersungguh-sungguh dalam mempelajari teori, konsep, hukum dan sikap ilmiah sesuai dengan pendekatan saintifik (Rosada dkk, 2017). Permendiknas RI No. 24 Tahun 2007 menjelaskan bahwa sarana dan prasarana laboratorium yang wajib tersedia di dalam laboratorium kimia meliputi perabotan, peralatan pendidikan, media pendidikan, dan bahan habis pakai.

Pemanfaatan laboratorium secara efektif merupakan salah satu syarat dalam pembelajaran kimia, khususnya pada materi praktikum. Namun, pada kenyataannya tidak semua sekolah dapat melaksanakan praktikum sesuai dengan tuntutan kurikulum. Menurut Wiratma dan Subagia (2014), permasalahan yang sering ditemui dalam pembelajaran di laboratorium yaitu pengelolaan laboratorium yang meliputi proses pengadaan, proses penggunaan, dan proses pemeliharaan. Permasalahan dalam proses pengadaan yaitu ketidaktepatan alat dan bahan yang datang dengan apa yang dibutuhkan. Permasalahan dalam proses penggunaan yaitu kesalahan pengoperasian alat dan bahan. Permasalahan dalam proses pemeliharaan yaitu kesalahan pada penataan alat dan bahan di laboratorium (Wiratma \& Subagia, 2014).

Pengadaan dikatakan baik apabila alat dan bahan yang datang sesuai dengan kebutuhan dari sekolah, kualitas baik, aman dalam penggunaan, dan mudah disimpan. Untuk alat yang berbentuk set, harus lengkap dan tidak kekurangan satu komponen pun (Lubis dkk, 1993). Penggunaan sarana laboratorium harus diprioritaskan untuk keterlaksanaan praktikum kimia. Penggunaan alat dan bahan praktikum yang baik dapat menunjang keterlaksanaan praktikum kimia sesuai dengan tuntutan dari kurikulum yang diterapkan oleh sekolah (Warsiti dkk, 2013). Dalam proses penggunaan alat dan bahan praktikum, laboran memiliki peranan yang cukup penting. Mulai dari mempersiapkan alat dan bahan sesuai permintaan, mencatat penggunaan, hingga menata kembali ke tempat semula merupakan tugas dari laboran (Wiratma \& Subagia, 2014). Pemeliharaan atau perawatan alat dan bahan sebaiknya dilakukan secara rutin (terjadwal) dan tercatat sehingga dapat memberikan informasi mengenai riwayat alat dan bahan, dari sejak awal pembelian, pemakaian, pemeliharaan, hingga habis masa pakai (Rosada dkk, 2017). Hal-hal yang perlu dipertimbangkan dalam menangani limbah laboratorium yaitu biaya pembuangan, potensi bahaya terhadap orangorang di luar laboratorium, dan dampaknya terhadap lingkungan (Moran \& Masciangioli, 2010).

SMA Negeri 1 Tampaksiring merupakan salah satu sekolah negeri terakreditasi A yang berada di kecamatan Tampaksiring, Gianyar. Laboratorium kimia yang ada masih digunakan sebagai ruangan kelas. Sekolah ini belum memiliki laboran yang dapat membantu persiapan praktikum maupun kegiatan pengelolaan laboratorium lainnya. Salah satu guru kimia menyatakan bahwa pelaksanaan praktikum di sekolah tersebut masih terbilang sangat minim. Pada ruangan alat dan bahan terlihat adanya penumpukan persediaan bahan sedangkan untuk persediaan alat terlihat sangat kurang. Penataan alat dan bahan belum disesuaikan dengan spesifikasikan dan hanya diletakkan begitu saja pada rak yang ada. Terlihat masih adanya alat dan bahan yang sudah rusak dan tidak layak pakai pada rak alat dan bahan yang layak pakai. Berdasarkan hasil studi pendahuluan tersebut, maka perlu diadakannya penelitian untuk mengetahui pengelolaan alat dan bahan praktikum di laboratirum kimia dan hambatan yang dialami pengelola dalam mengelola alat dan bahan praktikum kimia di SMA Negeri 1 Tampaksiring. Tujuan dari penelitian ini adalah untuk mendeskripsikan dan menjelaskan proses pengelolaan dan hambatan yang dialami pengelola dalam mengelola alat dan bahan praktikum laboratorium kimia di SMA Negeri 1 Tampaksiring dilihat dari aspek perencanaan pengadaan, pengadaan, penggunaan, pemeliharaan, inventarisasi alat dan bahan, serta pemusnahan alat dan bahan dan rusak. 


\section{METODE}

Penelitian ini merupakan penelitian kualitatif dengan pendekatan fenomenologi. penelitian dilakukan di SMA Negeri 1 Tampaksiting. Sumber data dalam peneletian ini meliputi dokumen pengelolaan laboratorium, wakasek sarana prasarana, ketua laboratorium kimia, guru- guru kimia, dan perwakilan siswa kelas XII IPA. Informasi yang dikumpukan dari masing-masing sumber yaitu isi dari dokumen pengelolaan, pendapat dan pengalaman dari wakasek sarana prsarana, ketua laboratorium kimia, guru-guru kimia, dan siswa terkait pengelolaan alat dan bahan praktikum kimia. Data yang dikumpulkan diperoleh dengan menggunakan berbagai teknik yang meliputi observasi, wawancara dan studi dokumen. Teknik observasi dilakukan dengan cara mengunjungi langsung laboratorium kimia dengan membawa lembar observasi untuk memperoleh data mengenai ketersediaan, penggunaan, serta pemeliharaan alat dan bahan praktikum kimia. Teknik wawancara digunakan untuk memperoleh data mengenai proses pengelolaan alat dan bahan praktikum serta hambatanhambatan yang dialami dalam mengelola alat dan bahan praktikum di labratorium kimia. Proses wawancara dilakukan dengan menggunakan pedoman wawancara dan melibatkan semua informan yang terlibat dalam proses pengelolaan yaitu wakasek sarana prsarana, ketua laboratorium kimia, guru-guru kimia, dan siswa. Teknik studi dokumen dilakukan dengan cara mengumpulkan beberapa dokumen berupa buku inventaris alat dan bahan praktikum, dan RKAS. Dokumen-dokumen tersebut dapat melengkapi data penelitian pada aspek perencanaan pengadaan, penggunaan dan inventarisasi alat dan bahan praktikum di laboratorium kimia. Analisis terhadap data yang telah diperoleh dilakukan dengan cara analisis sebelum di lapangan dan selama di lapangan. Analisis selama di lapangan dilakukan dengan menggunakan model Miles \& Huberman yang meliputi data reduction, data display, dan conclution drawing/verification (Sugiyono, 2014). Pengujian keabsahan data dilakukan dengan menggunakan teknik triangulasi sumber dan triangulasi teknik. Peneliti melakukan pembandingan terhadap data hasil wawancara dengan data yang diperoleh dari observasi dan studi dokumen untuk menemukan jawaban dari rumusan masalah dalam penelitian ini. Hasil wawancara dikuatkan dengan melakukan member check.

\section{HASIL DAN PEMBAHASAN}

Pengelolaan laboratorium meliputi enam aspek, yaitu perencanaan, pengadaan, penggunaan, pemeliharaan, inventarisasi alat dan bahan, serta pemusnahan alat dan bahan yang rusak. Proses perencanaan pengadaan alat dan bahan praktikum kimia di SMA Negeri 1 Tampaksiring sudah berjalan dengan baik. Berdasarkan hasil wawancara, diketahui bahwa proses perencanaan melibatkan guru-guru kimia, ketua laboratorium kimia, dan wakasek sarana prasarana. Guru-guru kimia melakukan analisis kebutuhan untuk membuat daftar usulan alat dan bahan yang perlu diadakan kembali. Daftar usulan tersebut diserahkan kepada ketua laboratorium untuk disampaikan kepada wakasek sarana prasarana untuk dimasukkan ke dalam RKAS (Rancangan Kegiatan Anggaran Sekolah). Sumber dana dalam proses pengadaan diperoleh dari pemerintah melalui dana BOS. Bantuan tersebut digunakan untuk memenuhi kebutuhan sekolah selama satu tahun. Apabila dana yang tersedia tidak mencukupi untuk memenuhi semua kebutuhan sekolah, maka sekolah akan membuat perencanaan berdasarkan skala prioritas. Proses perencanaan pengadaan di SMA Negeri 1 Tampaksiring sudah sesuai dengan Peraturan Presiden RI Nomor 54 Tahun 2010 yaitu dengan mengadakan anaisis kebutuhan dan menyusun rencana anggaran yang diperlukan.

Proses pengadaan alat dan bahan praktikum di SMA Negeri 1 Tampaksiring dilakukan melalui pembelian sendiri oleh sekolah melalui rekanan. Setelah penyusunan RKAS disetujui oleh pemerintah, kemudian direalisasikan oleh sekolah dengan pembelian alat dan bahan praktikum. Proses pengadaan langsung tersebut sesuai dengan Peraturan Presiden RI Nomor 54 Tahun 2010, yang menyebutkan bahwa pengadaan langsung dapat dilakukan terhadap pengadan barang dengan harga paling tinggi Rp 100,000.000 (seratus juta rupiah), barang yang diadakan merupakan barang operasional instansi, teknologi sederhana, memiliki resiko kecil, dan dilaksanakan oleh penyedia atau badan usaha kecil. Pengadaan dilakukan secara berkala yaitu setiap dimulainya tahun ajaran baru, namun tidak menutup kemungkinan adanya pengadaan secara insidental, khususnya untuk bahan-bahan habis pakai seperti aquades, baterai, dan kertas saring.

Namun, proses pengadaan yang diakukan oleh sekolah masih terkendala oleh dana. Dikarenakan kebutuhan sekolah melebihi dari dana yang tersedia, maka sekolah harus melakukan prioritas dalam pemesanan alat dan bahan praktikum yang diperlukan. Meskipun sekolah tidak pernah mengalami kesalahan dalam proses pengadaan, namun dikarenakan 
keterbatasan dana tersebut, tidak semua alat maupun bahan yang butuhkan dapat diadakan pada tahun anggaran tersebut.

Proses penggunaan alat dan bahan praktikum kimia melibatkan guru-guru kimia, ketua laboratorium, dan siswa. Sebelum melakukan praktikum, guru kimia berkoordinasi dengan ketua laboratorium kimia terkait jadwal penggunaan laboratorium maupun peminjaman alat dan bahan, kemudian guru yang bersangkutan akan mempersiapkan alat dan bahan yang diperlukan. Guru belum melibatkan siswa dalam proses persiapan rencana peminjaman alat dan bahan yang diperlukan. Hal tersebut belum sesuai dengan prisip dari Kancono (2010) yang menyatakan bahwa sebelum melaksanakan praktikum, siswa harus mempersiapkan rencana alat dan bahan yang akan dipakai untuk dipinjam melalui laboran dengan cara mengisi formulir peminjaman. Selanjutnya merupakan peran dari laboran yaitu mulai dari mempersiapkan alat dan bahan yang diperlukan, mencatat penggunaan, dan menata kembali setelah digunakan (Wiratma \& Subagia, 2014). Praktikum tidak selalu dilakukan di dalam laboratorim, dikarenakan laboratorium kimia yang ada digunakan sebagai kelas tetap oleh X IPA 5. Untuk praktikum yang dilakukan di dalam kelas, guru akan meminta perwakilan kelas untuk membantu memindahkan alat dan bahan dari laboratorium menuju kelas. Siswa juga kerap ditugaskan untuk membawa bahan-bahan praktikum yang sekiranya bisa dibawa dari rumah masing-masing, seperti air jeruk, cuka makanan, air sabun, air kunyit, dan garam dapur.

Secara umum proses penggunaan alat dan bahan praktikum kimia di SMA Negeri 1 Tampaksiring belum berjalan optimal. Selain dikarenakan belum terlibatnya siswa dalam proses persiapan sebelum praktikum dilaksanakan, juga dikarenakan minimnya pelaksanaan paktikum yang berjalan selama ini. Dari empat materi praktikum kelas $X$ yang dianjurkan dalam kurikulum hanya satu yang diprogramkan dan hanya dapat didemonstrasikan yaitu pembuktian hukum lavoisier. Dari 12 materi praktikum kelas XI yang dianjurkan dalam kurikulum hanya sembilan materi praktikum yang diprogramkan dan hanya empat materi yang terlaksana yaitu percobaan indikator alam dan indikator kimia, membedakan asam atau basa lemah dengan asam atau basa kuat, percobaan titrasi asam basa, dan membuat larutan penyangga dengan $\mathrm{pH}$ tertentu. Untuk materi kelas XII, dari enam materi yang dianjurkan dalam kurikulum tidak ada satupun yang terlaksana. Minimnya penggunaan alat dan bahan praktikum kimia dikarenakan beberapa hambatan yaitu tidak adanya laboran yang membantu persiapan, minimnya ketersediaan bahan, minimnya waktu yang dimiliki ditambah adanya libur, dan digunakannya laboratorium sebagai ruangan kelas tetap yaitu oleh kelas X IPA 5.

Proses pemeliharaan alat dan bahan kimia melibatkan ketua laboratorium, guru kimia, dan pegawai yang ditugaskan oleh sekolah untuk membantu mengelola laboratorium. Pemeliharaan diluar praktikum hanya dilakukan dengan penataan kembali alat dan bahan yang dirasa kurang rapi dan tidak sesuai dengan spesifikasinya. Sementara untuk alat-alat yang digunakan untuk praktikum, dilakukan pembersihan, seperti mencuci alat, setelah praktikum usai dan mengembalikan alat maupun bahan pada tempatnya. Alat-alat yang rusak belum mendapatkan penanganan khusus, hanya diletakkan terpisah dengan alat-alat yang layak pakai. Sementara untuk bahan-bahan yang sudah rusak masih ditempatkan pada rak penyimpanan bahan.

Berdasarkan hasil observasi diperoleh data bahwa pemeliharaan alat dan bahan belum dilakukan secara optimal. Penyimpanan beberapa alat, seperti labu dasar bulat, gelas arloji, buret, pipet ukur, corong pisah, cawan penguap, lumpang, alu, dan pelat tetes disimpan di dalam lemari yang terpisah dari alat-alat yang sejenis. Statif dan klem yang ada sudah mulai berkarat dan belum ada pengecatan kembali terhadap alat-alat tersebut. Penyimpanan neraca analitik masih dilakukan dengan menempatkan neraca didalam lemari bersama alatalat lainnya. Kalibrasi terhadap alat-alat listrik belum pernah dilakukan karena sekolah belum memiliki teknisi atau orang yang ahli yang dapat membantu.

Beberapa bahan belum disimpan sesuai dengan spesifikasinya. Penyimpanan bahan-bahan masih berdekatan antara satu bahan dengan bahan lainnya dan di dalam laboratorium hanya terdapat satu rak untuk penyimpanan bahan. Beberapa bahan juga ada yang terpisah dari bahan yang sejenis. Di dalam rak juga masih terdapat bahan- bahan kimia yang sudah kadaluarsa.

Pemeliharaan yang kurang optimal tersebut dikarenakan adanya beberapa permasalahan. Permaslahan utama yaitu mengenai waktu. Dikarenakan jadwal mengajar yang padat dan berbeda-beda, serta tidak adanya laboran atau tenaga ahli yang dapat membantu pemeliharaan laboratorium, guru-guru sulit menentukan jadwal yang pasti untuk melaksanakan pemeliharaan dan hanya dilakukan secara insidental. Sementara, menurut 
Rosada dkk (2017) kegiatan pemeliharan dan perawatan alat dan bahan praktikum sebaiknya dijadwalkan dan tercatat sehingga dapat memberikan informasi mengenai riwayat alat dan bahan, dari sejak awal pembelian, pemakaian, pemeliharaan, hingga habis masa pakai. Kendala lain yaitu mengenai ketersediaan lemari penyimpan yang masih minim, sehingga beberapa alat dan bahan yang tersimpan tidak sesuai dengan spesifikasinya.

Proses inventarisasi alat dan bahan praktikum melibatkan guru-guru kimia, ketua laboratorium dan pegawai yang ditunjuk oleh sekolah untuk membantu mengadministrasi perlengkapan laboratorium. Proses inventarisasi tidak dilakukan secara rutin, namun hanya dilakukan ketika barang baru datang dan ketika guru-guru melakukan pengecekan sebelum menyusun daftar pesanan pengadaan alat dan bahan baru. Berdasarkan hasil studi dokumen, diketahui bahwa data dokumen inventarisasi yang ada baik alat maupun bahan tidak mencantumkan kolom spesifikasi dan tanggal pengadaan alat maupun bahan. Pada dokumen inventarisasi alat, hanya dicantumkan kolom jumlah alat yang rusak tanpa pilihan rusak ringan atau parah. Sementara pada dokumen inventarisasi bahan, tidak dilengkapi kolom kondisi bahan. Terdapat beberapa perbedaan antara catatan pada dokumen inventarisasi dengan ketersediaan alat dan bahan di sekolah. Perbedaan tersebut terlihat pada jenis alat dan bahan yang tersedia dengan yang tercatat dalam dokumen.

Proses inventarisasi juga terhambat oleh waktu dan tenaga ahli. Dikarenakan jadwal mengajar guru-guru yang padat dan tidak adanya petugas laboratorium atau laboran yang mengetahui dengan baik alat dan bahan kimia yang dapat membantu. Dalam Kertiasa (2006) dijelaskan bahwa inventarisasi pada dasarnya dapat dilakukan oleh staf administrasi sekolah, bersama-sama dengan pengadministrasian barang inventaris dan bahan keperluan sekolah. Namun, dikarenakan banyaknya jenis alat dan bahan kimia, sekolah harus mencatat jenis/nama, jumlah/banyak, dan spesifikasi alat, serta nama dan alamat perusahaan, sehingga inventarisasi alat dan bahan praktikum sebaiknya dilakukan oleh guru atau orang yang terlatih khusus untuk menjadi petugas laboratorium (Kertiasa, 2006).

Proses pemusnahan melibatkan wakasek sarana prasarana, ketua laboratorium dan guru-guru kimia. Proses pemusnahan tidak memiliki jadwal khusus dan hanya dilakukan secara insidental. Alat-alat yang rusak dikumpulkan terlebih dahulu dalam sebuah kardus dan disimpan di ruangan alat dan bahan. Setelah kardus tersebut penuh, selanjutnya sekolah menyerahkan kepada petugas kebersihan untuk dibuang ke tempat pembuangan akhir (TPA). Sementara untuk limbah bahan hasil kegiatan praktikum, langsung dibuang melalui saluran air saat siswa membersihkan alat yang digunakan untuk praktikum. Pemusnahan terhadap bahan- bahan yang sudah kadaluarsa dilakukan dengan penuangan ke dalam lubang yang dibuat disekitar lingkungan sekolah pada kurun waktu tertentu. Untuk botol-botol bekas wadah bahan yang terbuat dari plastik akan dibakar dan botol-botol kaca akan dibuang bersama alat-alat praktikum yang rusak.

Proses pemusnahan belum sempat dilakukan beberapa tahun belakangan ini,dikarena adanya kendala pada penentuan tempat pembuatan lubang pembuangan. Tidak adanya tempat khusus dan aman untuk membuang bahan-bahan yang rusak menjadi kendala dalam proses pemusnahan. Selain itu, kurangnya pengetahuan mengenai langkahlangkah yang benar dalam pemusnahan alat dan bahan praktikum yang sesuai dengan aturan yang berlaku, juga menjadi kendala dalam proses pemusnahan.

Secara umum, proses pengelolaan alat dan bahan praktikum kimia di SMA Negeri 1 Tampaksiring belum berjalan optimal. Hal tersebut terlihat dari adanya ketidaksesuaian proses pengelolaan yang berjalan dengan standar pengelolaan yang berlaku. Proses pengelolaan juga masih terkendala oleh beberapa hal seperti waktu, tenaga ahli, ketersediaan dana, dan laboratorium yang digunakan sebagai ruangan kelas.

\section{SIMPULAN DAN SARAN}

Berdasarkan hasil penelitian dan pembahasan dapat disimpulkan beberapa hal sebagai berikut. 1) Proses perencanaan dilakukan dengan membuat daftar pesanaan alat sesuai dengan analisis kebutuhan, kemudian akan diserahkan kepada wakasek sarana prasarana untuk diajukan dalam RKAS. 2) Proses pengadaan dilakukan dengan pembelian sendiri menggunakan dana BOS. 3) Penggunaan alat dan bahan praktikum kimia hanya untuk praktikum siswa. 4) Proses pemeliharaan tidak dilakukan secara rutin dan belum melibatkan tenaga ahli. 5) Dalam kegiatan inventarisasi hanya dilakukan pencatatan jumlah alat dan bahan tanpa mencantumkan kondisi dari alat dan bahan yang ada. 6) Pemusanahan dilakukan dengan pembuangan ke tempat pembuangan akhir dan penuangan bahan yang 
rusak ke dalam lubang yang dibuat saat pemusnahan dilakukan. 7) Proses pengelolaan mengalami beberapa hambatan yang meliputi ketersediaan dana, waktu, digunakannya laboratorium sebagai ruangan kelas dan tidak adanya tenaga ahli yang dapat membantu, serta kurangnya pemahaman pegelola mengenai standar pengelolan laboratorium yang berlaku.

Berdasarkan hasil dan temuan dari penelitian ini, dipandang perlu untuk mengemukakan beberapa saran sebagai berikut. 1) Sekolah diharapkan memiliki pedoman pengelolaan laboratorium yang sesuai standar, merekrut tenaga ahli atau laboran, dan menggunakan laboratorium sesuai fungsinya. 2) Kepala sekolah disarankan melakukan kerjasama dengan komite sekolah untuk memprogramkan pengadaan alat dan bahan sesuai dengan standar minimal yang ada. 3) Guru-guru kimia disarankan agar lebih kreatif dan inovatif dalam melaksanakan pembelajaran praktikum. 4) Pengelola laboratorium diharapkan lebih meningkatkan kinerjanya dan memperjelas tupoksi dari masing-masing petugas yang terlibat. 5) Peneliti selanjutnya disarankan agar dapat meneliti lebih lanjut pengelolaan alat dan bahan praktikum di sekolah lainnya baik negeri maupun swasta.

\section{DAFTAR PUSTAKA}

BSNP. 2006. Standar Isi untuk Satuan Pendidikan Dasar dan Menengah: Standar Kopentensi dan Kopetensi Dasar SMA/MA. Jakarta

Depdiknas. 2003. Undang-Undang Sistem Pendidikan Nasional. Jakarta: Kemdiknas.

Kancono. 2010. Manajemen Laboratorium IPA: Persiapan bagi Pendidik, Mahasiswa, dan Laboran IPA. Bengkulu: Unit Penerbitan FKIP UNIB.

Kertiasa, N. 2006. Laboratorium Sekolah dan Pengelolaanya. Bandung: Pudak Scientific.

Lubis, H. M., Suna, R., Refirman, Moedjadi, Wiranto, \& Genda, M.

A. 1993. Materi Pokok Pengelolaan Laboratorium IPA; PGPA3930/3SKS. Jakarta: Universitas Terbuka, Depdikbud.

Moran, L., \& Masciangioli, T. (Ed.). 2010. Keselamatan dan Keamanan Laboratorium Kimia: Panduan Pengelolaan Bahan Kimia dengan Bijak. Amerika Serikat: The National Academies Press.

Peraturan Menteri Pendidikan Nasional Republik Indonesia Nomor 24 tahun 2007. Tentang Standar Sarana dan Prasarana untuk Sekolah Dasar/Madrasah Ibtidaiyah (SD/MI), Sekolah Menengah Pertama/Madrasah Tsanawiyah (SMP/MTs), dan Sekolah Menengah Atas/Madrasah Aliyah (SMA/MA).

Peraturan Presiden Republik Indonesia Nomor 54 Tahun 2010. Tentang PengadaanBarang/Jasa Pemerintah.

Rosada, D., Kadarisman, N., \& Raharjo. 2017. Panduan Pengelolaan dan Pemanfaatan Laboratorium IPA. Jakarta: Kemendikbud.

Sugiyono. 2014. Metode Penelitian Pendidikan (Kuantitatif, Kualitatif, dan R\&D). Bandung: Alfabeta.

Warsiti, Ngalim, A., Sumardi. 2013. Pengelolaan Laboratorium Kimia di SMA Negeri 1 Boyolali Tahun 2013. Naskah Publikasi IImiah. Surakarta: Universitas Muhammadiyah Surakarta.

Wiratma, I G. L., \& Subagia, I W. 2014. Pengelolaan Laboratorium Kimia pada SMA Negeri di Kota

Singaraja: (Acuan Pengembangan Model Panduan Pengelolaan Laboratorium Kimia Berbasis Kearifan Lokal Tri Sakti). Jurnal Pendidikan Indonesia. 3(2) (hal: 425 - 436). 